\title{
Decolorization of Wastewater from a Livestock Barn Using Andosols
}

\author{
Tatsuma MORI, Michio SAKIMOTO, \\ Tadaaki MORI ${ }^{1}$ and Takuo SAKAI ${ }^{2}$ \\ Osaka Agricultural and Forestry Research Center, Habikino-shi 583 \\ ${ }^{1}$ Mori Plant K.K., Abeno-ku, Osaka-shi 545 \\ ${ }^{2}$ Faculty of Agriculture, Kinki University, Nara-shi 631
}

(Received May 14, 1997)

\begin{abstract}
Andosol collected from Daisen in Tottori prefecture was found to be a potent decolorizer, i.e., an absorber of brown pigments, of wastewater from swine barns. A 30-day operation was performed for the decolorization of the wastewater using a column reactor containing $500 \mathrm{~g}$ of the soil. The operation resulted in high removal efficiencies of not only color $(76.9 \%)$ but also chemical oxygen demand $(69.8 \%)$ and phosphate $(84.7 \%)$ simultaneously from the wastewater.
\end{abstract}

Anim. Sci. Technol. (Jpn.) 68 (10): 940-947, 1997

Key words : Andosol, Decolorization, Wastewater

Wastewater from livestock barns is biologically treated by an activated sludge process prior to discharge. Most of the organic matter, nitrogen, and phosphate in wastewater are removed by this treatment. However, dark brown pigments in wastewater, which are the so-called melanoidins or humic acids ${ }^{8)}$, are hardly removed by the treatment. Since wastewater containing such pigments are highly responsible for visual pollution of wastewater. methods for decolorizing wastewater have received increased attention. Decomposition of dark brown pigments, which are very similar in chemical composition and structure $^{2,6,7,14,19)}$, is difficult with microorganisms. Thus, chemical or physical methods such as oxidation by ozone or hydrogen peroxide or absorption by activated charcoal ${ }^{3.4 .9 .13 .17)}$ have been used in human sewage treatment plants and in fermentation industries. However, these systems are not suited to the animal industry because they involve very high initial and operating costs. Recently, we found that andosols collected from Daisen in Tottori prefecture had a highly potent decolorizing ability for dark brown-colored wastewater. The present study describes experiments in which wastewater from a livestock barn was decolorized by the soil.

\section{Materials and Methods}

\section{Quality of effiuent of activated sludge process}

Swine wastewater, which was treated by an activated sludge process, was used. This water is referred to as effluent of activated sludge process (ASE). The quality of the ASE was as follows: absorbance at $410 \mathrm{~nm}\left(\mathrm{~A}_{410}\right)$, $0.201 ; \mathrm{pH}, 6.8$; biochemical oxygen demand (BOD), $49.8 \mathrm{mg} / l$; chemical oxygen demand (COD), $121.0 \mathrm{mg} / l$; phosphate $\left(\mathrm{PO}_{4}{ }^{3-}\right), 54.4 \mathrm{mg} / l$ ; suspended solids (SS), $79.8 \mathrm{mg} / l$; Kjeldahl 
nitrogen $(\mathrm{K}-\mathrm{N}), \quad 25.4 \mathrm{mg} / l$; nitrate nitrogen $\left(\mathrm{NO}_{3}-\mathrm{N}\right), 22.7 \mathrm{mg} / l$; ammonium nitrogen $\left(\mathrm{NH}_{4}{ }^{-}\right.$ $\mathrm{N}), 3.8 \mathrm{mg} / l$; transparency, more than $30 \mathrm{~cm}$.

\section{Screening of soils capable of decoloriz-} ing the ASE

Various soil samples were dried at $105^{\circ} \mathrm{C}$ for $24 \mathrm{~h}$, crushed in a mortar with a pestle, and sieved through a screen. A half gram of each soil sample was packed into a glass column (10 $\mathrm{mm}$ inside diameter, $250 \mathrm{~mm}$ length), and the column was washed with $20 \mathrm{~m} l$ of distilled water. After washing the column, $10 \mathrm{ml}$ of the ASE were filtered through the column, and the effluent was collected and pooled. The absorption of the pooled effluent at $410 \mathrm{~nm}$ was obtained. The decolorization rate $(\%)$ of the ASE by the sample was calculated by the following equation: $(A-B) / A \times 100$, where $A$ is the $A_{410}$ of the ASE before decolorization and $B$ is the $\mathrm{A}_{410}$ of the effluent.

The decolorizing capacity of a sample was determined as follows. One gram of the sample was packed into a glass column $(10 \mathrm{~mm}$ inside diameter, $250 \mathrm{~mm}$ length), and the column was washed with $40 \mathrm{ml}$ of distilled water. Three hundred $\mathrm{m} l$ of the ASE were pumped through the column at $30 \mathrm{ml} / \mathrm{h}$ with a peristaltic pump (ATTOSJ 1220, Tokyo), and the effluent was collected in $3-\mathrm{m} l$ fractions with a fraction collector (ADVANTEC SF-2120, Tokyo). The decolorization rate of each fraction was determined. The decolorizing capacity of the sample was estimated from the total volume of fractions that exhibited a decolorization rate of $60 \%$ or more.

\section{Operation of a column reactor contain-} ing andosols for 30 days

A column reactor for decolorizing the ASE was made as follows (Fig. 1). Gravel ballast $(100 \mathrm{~g}$ wet weight) was placed on the bottom of a ceramic container (inside diameter, $14 \mathrm{~cm}$; depth, $11 \mathrm{~cm}$ ) and then $500 \mathrm{~g}$ wet weight of the andosols (not dried, moisture 40.6\%) that had been previously filtered through $3 \mathrm{~mm}$ mesh, was laid on the gravel layer $(7.5 \mathrm{~cm}$ thick).

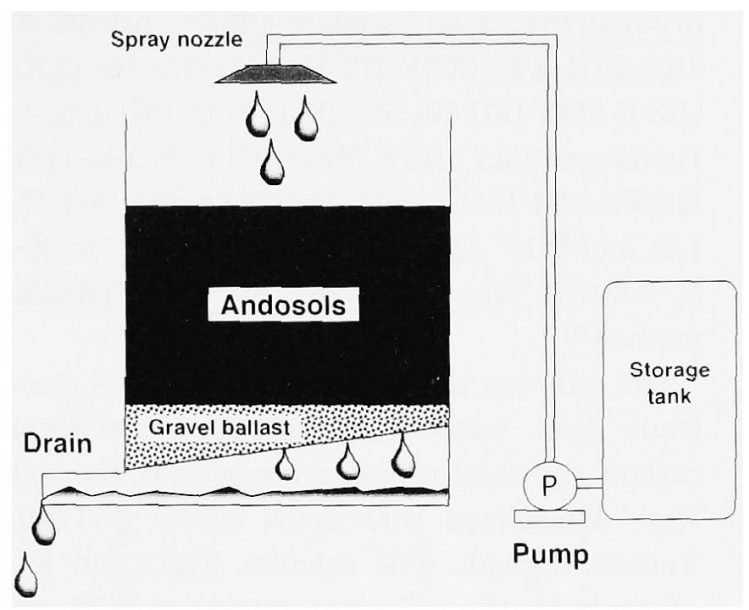

Fig. 1. A column reactor containing andosols for decolorizing the ASE.

One hundred grams of gravel ballast were placed on the bottom of a ceramic container and then $500 \mathrm{~g}$ of ADT (wet weight) which was filtered through $3 \mathrm{~mm}$ mesh were laid on the gravel ballast layer. The surface of the ADT layer was sprayed with $100 \mathrm{~m} l$ of the ASE with a peristaltic pump $(50 \mathrm{ml} / \mathrm{h})$ for $2 \mathrm{~h}$ a day. The effluent from the drain of the column reactor was pooled every 10 days.

The column reactor was operated for 30 days as follows. One hundred $\mathrm{m} l$ of the ASE were sprayed on the surface of the andosol layer for $2 \mathrm{~h}$ a day with a peristaltic pump $(50 \mathrm{ml} / \mathrm{h})$. The effluent from the drain, which was kept at $4^{\circ} \mathrm{C}$, was pooled every 10 days and then analyzed $\left(\mathrm{A}_{410}, \mathrm{pH}, \mathrm{COD}, \mathrm{SS}, \mathrm{K}-\mathrm{N}, \mathrm{NO}_{3}-\mathrm{N}, \mathrm{NH}_{4}-\right.$ $\mathrm{N}$, and $\left.\mathrm{PO}_{4}{ }^{3-}\right)$. In the following, data at days 10,20 and 30 refer to the first, second and third 10-day periods, respectively. The data shown in this report are the averages with standard deviations in three operations carried out under the same conditions.

\section{Analytical methods}

The amount of dark brown color in the ASE was measured spectrophotometrically at 410 $\mathrm{nm}$ with a $1 \mathrm{~cm}$ light path cuvette using a U2000 spectrophotometer (Hitachi, Japan). The qualities of the ASE and processed ASE were measured according to the methods described 
in Japan Industrial Standard (JIS) ${ }^{12)}: \mathrm{pH}$ (JIS K 0102-1971 8. 1), BOD (JIS K 0102-1971 16), COD (JIS K 0102-1971 13), SS (JIS K 0102-1971 10.2.1. 1), transparency (JIS K 0102-1971 6), $\mathrm{NO}_{3}-\mathrm{N}$ (JIS $\mathrm{K}$ 0102-1971 17.3.1), $\mathrm{NH}_{4}-\mathrm{N}$ (JIS K 0102-1971 17. 1.2), and $\mathrm{PO}_{4}{ }^{3-1}$ (JIS K 0102-1971 27.1). The $\mathrm{K}$ $\mathrm{N}$ content was measured by the Kjeldahl method $^{18)}$.

Soil $\mathrm{pH}$ was determined with a glass electrode (soil water ratio $10: 25$ ). The total carbon and total nitrogen contents in the soil were determined with a CN corder (MT500, Yanaco, Japan). The calcium, $\mathrm{Mg}^{2+}$ and $\mathrm{K}^{+}$ contents in the soil were measured with an atomic absorption spectrophotometer (Hitachi, 170-10, Japan). The $\mathrm{NH}_{4}-\mathrm{N}$ content (method of Harper), $\mathrm{NO}_{3}-\mathrm{N}$ content (phenol sulfate method), $\mathrm{P}_{2} \mathrm{O}_{5}$ content (method of Lorenz), and cation exchange capacity value (method of Schollenberger) in the soil were also determined $^{5)}$. All chemicals used for analysis were purchased from Wako Pure Chemical Co., Ltd (Japan), and were of analytical grade.

\section{Results}

\section{Ability of various soils to decolorize $A S E$}

Nine soil samples collected from different districts were tested (Table 1). Andosols collected from Daisen in Tottori prefecture (ADT) had the highest potent decolorizing ability, removing $76.8 \%$ of the dark brown pigments in the ASE. Andosols collected from Kumamoto prefecture and Osaka prefecture had lower decolorizing abilities $(52.9 \%$, and $21.9 \%$, respectively). In contrast, no decolorizing abilities were observed for yellow soil, red soil, diatomaceous earth, zeolite or sea sand. Therefore, ADT was used in this study. The soil composition of the ADT is shown in Table 2.

Figure 2 shows the change in decolorization rate during filtration of $300 \mathrm{ml}$ of the ASE with $1 \mathrm{~g}$ of the ADT. The decolorization rate was maintained above $95 \%$ until the total quantity of the ASE filtered was $10 \mathrm{~m} l$ and then fell gradually, reaching $60 \%$ after a total flow of 60 $\mathrm{ml}$. Based on these results, $1 \mathrm{~g}$ (dry weight) of ADT was estimated to be capable of decolorizing $60 \mathrm{~m} l$ of ASE. For comparison, activated charcoal (Katayama Chemical, Japan) was

Table 1. Decolorization ability of various soil for dark brown-colored ASE

\begin{tabular}{lcc}
\hline \multicolumn{1}{c}{ Sample } & A $_{410}$ & $\begin{array}{c}\text { Decolorization } \\
\text { rate }(\%)\end{array}$ \\
\hline Andosols from Daisen-cho in Tottori prefecture & 0.047 & 76.8 \\
Andosols from Gotenba-shi in Sizuoka prefecture & 0.202 & 0 \\
Andosols from Nose-cho in Osaka prefecture & 0.158 & 21.9 \\
Andosols from Kumamoto-shi in Kumamoto prefecture & 0.107 & 52.9 \\
Red soils from Habikino-shi in Osaka prefecture & 0.202 & 0 \\
Yellow soils from Habikino-shi in Osaka prefecture & 0.202 & 0 \\
Diatomaceous earth* & 0.202 & 0 \\
Zeolite* & 0.200 & 1.0 \\
Sea sand $^{*}$ & 0.200 & 1.0 \\
\hline
\end{tabular}

Ten $\mathrm{m} l$ of ASE was filtered through a glass column packed with $0.5 \mathrm{~g}$ of sample. Effluent was collected, and $\mathrm{A}_{410}$ of the effluent was determined. The decolorization rate (\%) was calculated by the following equation: $(A-B) / A \times 100$, where $A$ is the initial value of $A_{410}$ and $B$ is the $A_{410}$ of decolorized waste water.

* ; Purchased from Wako Pure Chemical. 
Wastewater Decolorization with Andosols

Table 2. Chemical composition of the ADT

\begin{tabular}{lclc}
\hline Moisture & $40.6 \%$ & $\mathrm{P}_{2} \mathrm{O}_{5}$ & $236.3 \mathrm{mg} / 1.00 \mathrm{~g}$ \\
$\mathrm{pH}$ & 5.3 & $\mathrm{NH}_{4}-\mathrm{N}$ & $\mathrm{ND}$ \\
Equivalent conductivity & $19.0 \mu \mathrm{s} / \mathrm{cm}$ & $\mathrm{NO}_{3}-\mathrm{N}$ & $1.3 \mathrm{mg} / 100 \mathrm{~g}$ \\
$\mathrm{Ca}^{++}$ & $0.9 \%$ & Cation exchange capacity & $10.2 \mathrm{me} / 100 \mathrm{~g}$ \\
$\mathrm{~K}^{+}$ & $107.5 \mathrm{mg} / 100 \mathrm{~g}$ & Total carbon & $6.8 \%$ \\
$\mathrm{Mg}^{++}$ & $2.0 \mathrm{mg} / 100 \mathrm{~g}$ & Total nitrogen & $0.3 \%$ \\
\hline
\end{tabular}

ND ; not detected.

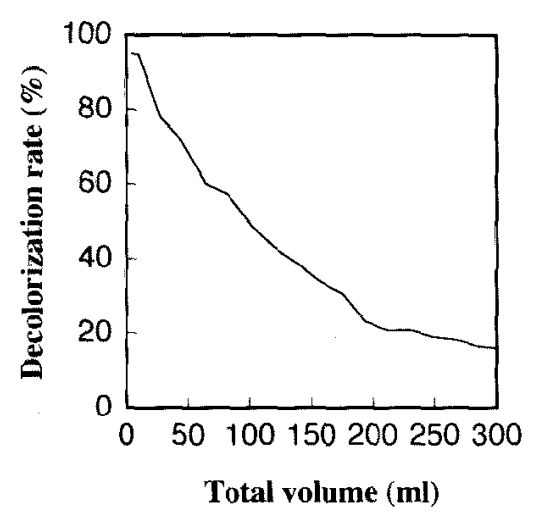

Fig. 2. Capacity of ADT to decolorize brown color in the ASE.

Three hundred $\mathrm{m} l$ of the ASE was filtered through a glass column containing $1 \mathrm{~g}$ of ADT $(30$ $\mathrm{m} l / \mathrm{h})$. The effluent was collected in $3-\mathrm{m} l$ fractions, and $A_{410}$ of each fraction was determined. The decolorization rate $(\%)$ was calculated by the following equation: $(A-B) / A X$ 100 . where $A$ is the initial value of $A_{410}$ and $B$ is the $\mathrm{A}_{410}$ of decolorized wastewater.

capable of decolorizing $150 \mathrm{~m} l$ of ASE, and thus had 2.5 times as much decolorizing capacity as ADT.

\section{Results of 30-day decolorizing experi- ments using a column reactor contain- ing $A D T$}

Figure 3 shows the changes in decolorization rate of the ASE during 30-day operation of the column reactor. Most of the dark brown pigments in the ASE were removed during the 30 day period (Fig. 4). The decolorization rates of the ASE at days 10, 20 and 30 were 94.0, 83.1, and $76.9 \%$, respectively. During operation, SS

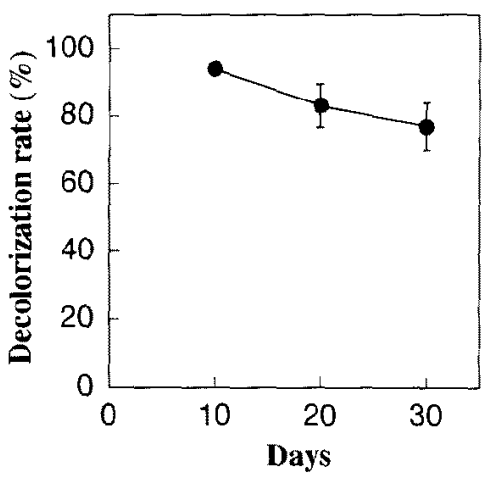

Fig. 3. Rate of decolorization of the ASE by the column reactor over a 30 -day period.

The ASE $\left(A_{410} ; 0.201,100 \mathrm{ml}\right.$ a day) was filtered at $50 \mathrm{rnl} / \mathrm{h}$ for $2 \mathrm{~h}$ through the colunn reactor for 30 days. The effluent from the drain was pooled every 10 days. The decolorization rate was calculated from the changes in $\mathrm{A}_{010}$ of the ASE before and after filtration by the equation described in Materials and Methods. Each point and vertical line indicate the mean $\pm S D$ of values in three operations.

in the ASE were completely removed, and no clogging of the ADT layer, i.e., no resistance to flow through the ADT layer, was observed. Most of the COD was removed $(69.8 \%$ at day 10 , $69.8 \%$ at day 20 and $73.1 \%$ at day 30 ) (Fig. 5). Most of the $\mathrm{PO}_{4}{ }^{3-}$ was also removed (100\% at day $10,91.7 \%$ at day 20 and $84.7 \%$ at day 30 ) (Fig. 6).

The column reactor also removed $85.6 \%$ of the $\mathrm{K}-\mathrm{N}$ in the ASE during the first 10 days, but in the subsequent 20 days, the $K-N$ values in the effluent were higher than the values in the 


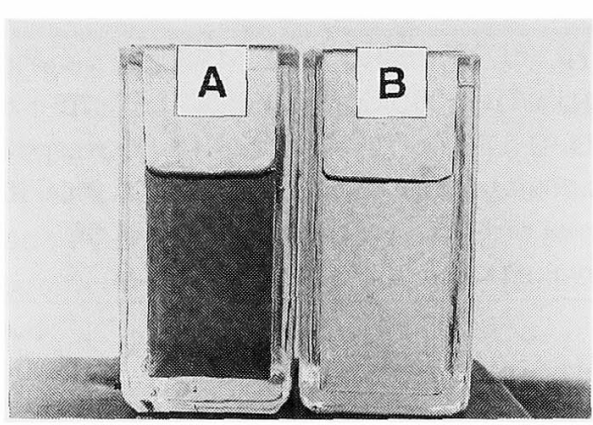

Fig. 4. Photographs of the ASE before (A) and after (B) decolorization by the column reactor.

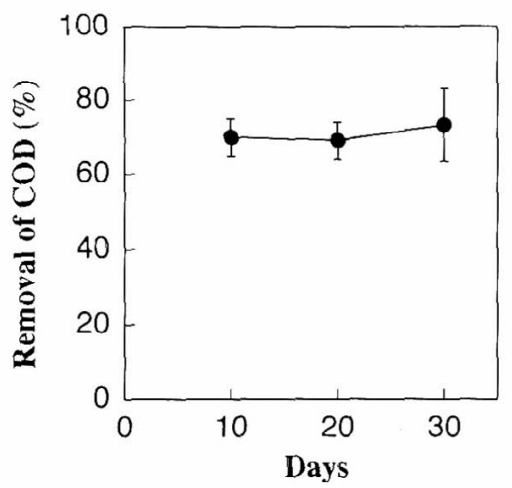

Fig. 5. Removal of COD in the ASE by the column reactor over a 30 -day period.

$100 \mathrm{ml} /$ day of the ASE (COD value; $121.0 \mathrm{mg} / \mathrm{l}$ ) was filtered at $50 \mathrm{ml} / \mathrm{h}$ for 30 days through the column reactor. The effluent from the drain was pooled every 10 days. The COD values of the pooled effluents were determined. Each point and vertical line indicate the mean $\pm S D$ of values in three operations.

ASE (10.2\% higher at day 20 and $83.5 \%$ higher at day 30) (Fig. 7). $\Lambda$ similar phenomenon was observed in the removal of $\mathrm{NO}_{3}-\mathrm{N}$. The $\mathrm{NO}_{3}-$ $\mathrm{N}$ was almost completely removed at day 10 , but it increased to $47.2 \%$ above the ASE value at day 20 and to $23.3 \%$ above the ASE value at day 30. Ammonium nitrogen in the ASE was not absorbed by the ADT. The column reactor slightly decreased the $\mathrm{pH}$ level of the ASE. The pH was 6.7 at day 10,6.3 at day 20 and 6.3 at day 30.

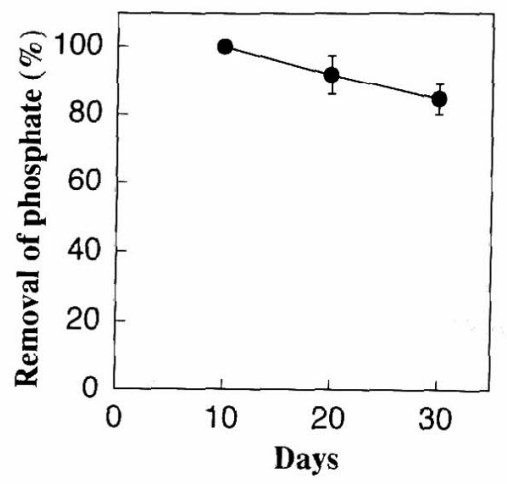

Fig. 6. Removal of phosphate in the ASE by the column reactor over a 30 -day period.

$100 \mathrm{ml} /$ day of the ASE $\left(\mathrm{PO}_{4}{ }^{3-}, 54.4 \mathrm{mg} / l\right)$ was filtered at $50 \mathrm{ml} / \mathrm{h}$ for 30 days through the column reactor. The effluent from the drain was pooled every 10 days. The $\mathrm{PO}_{4}{ }^{3-}$ of the effluents were determined. Each point and vertical line indicate the mean $\pm \mathrm{SD}$ of values in three operations.

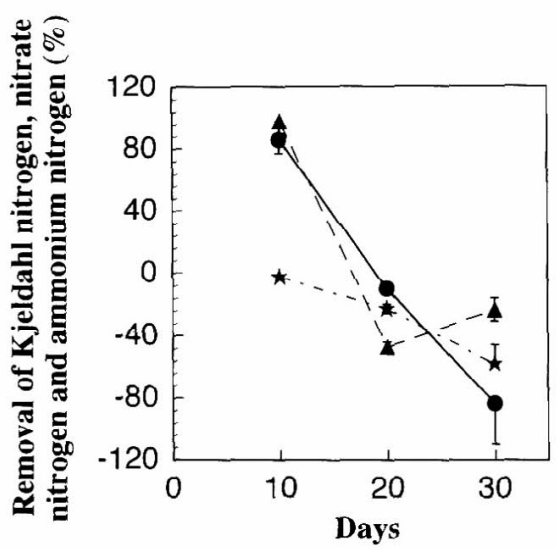

Fig. 7. Removal of Kjeldahl nitrogen, nitrate nitrogen and ammonium nitrogen by the column reactor over a 30-day period.

$100 \mathrm{ml} /$ day of the ASE $\left(\mathrm{K}-\mathrm{N}, 25.4 \mathrm{mg} / l ; \mathrm{NO}_{3}-\mathrm{N}\right.$, $\left.22.7 \mathrm{mg} / l ; \mathrm{NH}_{4}-\mathrm{N}, 3.8 \mathrm{mg} / l\right)$ was filtered at $50 \mathrm{ml} /$ $h$ for 30 days through the column reactor. The effluent from the drain was pooled every 10 days. The $\mathrm{K}-\mathrm{N}$ value $(\boldsymbol{O}), \mathrm{NO}_{3}-\mathrm{N}$ value $(\boldsymbol{\Delta})$ and $\mathrm{NH}_{4}-\mathrm{N}$ value $(\star)$ of the effluents were determined. Each point and vertical line indicate the mean $\pm \mathrm{SD}$ of values in three operations. 


\section{Discussion}

Among the soil samples tested, the ADT was the most potent decolorizer of ASE (76.8\%). This soil, which contains allophane, is typical of volcanic ash soil. It has been reported that such soils have a high anion exchange capacity and a high specific surface area ${ }^{1,15)}$. In contrast, these parameters are reported to be very poor in non-volcanic ash soils such as red soil. The cation exchange capacity of the ADT was $10.2 \mathrm{me} / 100 \mathrm{~g}$, which is low in comparison with the values reported for other types of soill, 10). Among the materials screened in this study, zeolite, which has a high cation exchange capacity, showed no decolorizing ability for dark brown pigments in the ASE. Based on these results, the color removal ability of the ADT may be due to its high anion exchange capacity and high specific surface area. Wastewater treatments by andosols have previously been reported by Inoue et $a l .{ }^{(1)}$ and Yamashita et $a l .{ }^{20)}$. In these reports, however, little attention was given to the fact that the dark brown pigments in wastewater are absorbed by the soil. We were unable to find any other reports on color removal from wastewater by soil except for a report by McGhee et al. ${ }^{16)}$ in which clayey sand was used for color removal from feedlot runoff.

During the 30-day decolorizing operation of the column reactor, a high removal efficiency for dark brown pigments in the ASE was obtained. The high decolorization rates that were observed in the processing of $3 l$ ASE over the 30-day period were consistent with the decolorizing capacity of the ADT reactor, which is estimated to be $18 l(500 \mathrm{~g}$ wet weight $\times 0.6 \mathrm{~g}$ dry weight $/ 1.0 \mathrm{~g}$ wet weight $\times 60 \mathrm{ml} / \mathrm{g}$ dry weight). During the operation, SS in the ASE were completely removed by the column reactor, and no clogging of the ADT layer was observed. Activated charcoal, which is widely used to decolorize wastewater in human sewage plants, was 2.5 times more effective as a decolorizer than ADT. However, ADT is more cheaper (about $1 / 75$ in price) than activated charcoal. Thus, ADT has a practical use as a filtering medium for decolorizing and can replace of activated charcoal.

The column reactor also exhibited a high removal efficiency of $\mathrm{COD}$ in the ASE (more than 70\%). As dark brown pigments are poorly biodegradable organic substances, the high removal rate of $C O D$ is assumed to be the result of high removal efficiency for dark brown pigments in the ASE. The $\mathrm{PO}_{4}{ }^{3-}$ in the ASE was also well removed (more than $80 \%$ ) by the column reactor. A high phosphorus absorption coefficient is a well-known characteristic of volcanic ash soils. The column reactor showed poor efficiencies in removing nitrogenous compounds from the ASE. During the first 10 days of operation, high removal of both $\mathrm{K}-\mathrm{N}$ and $\mathrm{NO}_{3}-\mathrm{N}$ in the ASE (more than $80 \%$ ) was observed, but in the following 20 days, the $\mathrm{K}-\mathrm{N}$ and $\mathrm{NO}_{3}-\mathrm{N}$ contents in the effuents were actually larger than their values in the ASE. This indicates that the absorption capacity of the ADT for nitrogenous components was low. The increase in $\mathrm{NO}_{3}-\mathrm{N}$ in the effluent observed from day 20 is probably caused by the elution of absorbed $\mathrm{NO}_{3}-\mathrm{N}$ in the column reactor. Since the column reactor has a water-holding capacity of about $400 \mathrm{~m} l$, it is also likely that the increase was due to the nitrification of $\mathrm{NH}_{4}-\mathrm{N}$ in the ASE held in the column reactor. In the case of $\mathrm{K}-\mathrm{N}$, the increase was probably caused by the elution of absorbed $\mathrm{K}-\mathrm{N}$ in the column reactor. As the Kjeldahl method determines organic nitrogen and $\mathrm{NH}_{4}-\mathrm{N}$, but not $\mathrm{NO}_{3}-\mathrm{N}$, it is also likely that the increase in $\mathrm{K}-\mathrm{N}$ is due to organic nitrogen synthesized microbiologically from the $\mathrm{NH}_{4}-\mathrm{N}$ in the ASE held in the column reactor. The poor ability of the column reactor to remove $\mathrm{NH}_{4}-\mathrm{N}$ is probably due to the poor cation exchange capacity of the ADT, because $\mathrm{NH}_{4}-\mathrm{N}$ in the ASE is a monovalent cation. The inability of soil treatment to remove nitrogenous compounds in the 
wastewater has also been pointed out by other researchers ${ }^{11,20)}$.

Based on these results, the use of ADT seems promising as an alternative method for the decolorizing of ASE. The advantages of ADT include: simultaneous removal of $\mathrm{COD}$ and phosphate in the ASE, a cheaper operational cost in the decolorizing process when compared with conventional methods using activated charcoal, and less environmental damage than is caused by chemical agents such as $\mathrm{H}_{2} \mathrm{O}_{2}$ for decolorizing.

\section{References}

1) Amano $Y$. Andisol teian to Nippon no kazanbaido (in Japanese). In : Kazanbaido. (Nippon Dojo-hiryo Gakkai ed.) 187-204. Hakuyusha. Tokyo. 1983.

2) Benzing-Purdie L, Ripmeester JA, Preston CM. Elucidation of the nitrogen forms in melanoidins and humic acid by nitrogen- 15 cross polarization-magic angle spinning nuclear magnetic resonance spectroscopy. J. Agric. Food Chem., 31 : 913-915. 1983.

3) Churchley JH. Removal of dyewaste colour from sewage effluent - the use of a full scale ozone plant. Water Sci. Technol., $30: 275-284$. 1994.

4) Constantine $T \Lambda$. Advanced water treatment for color and organics removal. J. Am. Water Works Assoc., 74 : 310-313. 1982.

5) Funahiki S, Aomine S. Shinsen Dojo Jikkenho (in Japanese). 79-97. Yokendo. Tokyo. 1965.

6) Hayase F, Kim SB, Kato H. Decolorization and degradation products of the melanoidins by hydrogen peroxide. Agric. Biol. Chem., 48: 2711-2717. 1984.

7) Hayase F, Kim SB, Kato $H$. Analyses of the chemical structures of melanoidins by ${ }^{13} \mathrm{C}$ NMR, ${ }^{13} \mathrm{C}$ and ${ }^{15} \mathrm{~N}$ CP-MAS NMR spectrometry. Agric. Biol. Chem., 50 : 1951-1957. 1986.

8) Hayase F. Chemistry of melanoidins (in Japanese). Nippon Nogeikagaku Kaishi, 61:970973. 1987.
9) Honda $T$, Kugawa Y. Recycling of sewage treatment water by ozone. Desalination, 98 : 327-334. 1994.

10) limura K. Acidic properties and cation exchange of allophane and volcanic ash soils. Bull. Natl. Inst. Agric. Sci. Ser. B., 17 : 101-154. 1966.

11) Inoue $T$, Shimatomi $O$, Ishiyama $H$, Taguchi $K$, Mori S. Disposal of liquid wastes using filters and plants. 1) Disposal of liquid wastes through soil and grasslands. Bull. Fukuoka Agric. Res. Cent., C-2 : 87-91. 1983.

12) Japanese Standards Association. Testing methods for industrial waste water. In : JIS handbook. 674-697. Tokyo. 1974.

13) Kaspar A. Studies on colour removal by activated charcoal. Text Dyer Printer, $27: 19-21$. 1994.

14) Kim SB, Hayase F, Kato H. Decolorization and degradation products of melanoidins on ozonolysis. Agric. Biol. Chem., 49:785-792. 1985.

15) Maeda $T$, Souma K. Kazanbaido no butsurisei to kougakusei (in Japanese). In : Kazanbaido. (Nippon Dojo-hiryo Gakkai ed.) 99-139. Hakuyusha. Tokyo. 1983.

16) McGhee TJ, Miller RA. Soil absorption of humic color. J. Water Pollut. Control Fed., 48 : 1970-1978. 1976.

17) Murata K, Yamada $Y$, Kawasugi T. Shi-nyoshorisui no ozonshori ni kansuru kenkyu (in Japanese). Mizushori Gijutsu, $19: 43-55.1978$.

18) Nippon Gesuido-Kyokai. Gesui Siken-ho (in Japanese). 113-116. Nippon Gesuido-kyokai. Tokyo. 1974.

19) Terasawa N, Murata M, Homma S. Separation of model melanoidin into components with copper chelating sepharose $6 \mathrm{~B}$ column chromatography and comparison of chelating activity. Agric. Biol. Chem., 55 : 1507-1514. 1991.

20) Yamashita H, Amahashi K, Araki S. Kachiku no nyo oyobi chikusha no dojo joka ni kansuru shiken (in Japanese). Bulletin of Hyogo Prefectural Experiment Station of Animal Husbandry, 19:152-155. 1982. 


\title{
黒ぼく土による畜産排水の脱色
}

\author{
森 達摩 . 崎元道男 $\cdot$ 森 忠明 $^{1} \cdot$ 坂井拓夫 ${ }^{2}$ \\ 大阪府立農林技術センター, 羽曳野市 583 \\ ${ }^{1}$ (株)モリプラント，大阪市阿倍野区 545 \\ ${ }^{2}$ 近畿大学農学部, 奈良市 631
}

鳥取県大山の黒ぼく土が養豚排水中の茶褐色々素を吸着する性質を持ち，排水の脱色用滤材として利 用できることを見いだした．500gの黒に゙くをを詰めたカラムリアクターを用いて 30 日間の排水の脱色 試験を行った結果, 高い脱色効果 (76.9\%) が認めら机，同時にCODの除去 $(69.8 \%)$ とリンの除去 (84.7\%) 効果も認められた。

日畜会報, $68(10) ： 940-947,1997$ 